\title{
«SIC ERAT SCRIPTUM, NEC POTUI ALITER LEGERE». SOME REMARKS ON THE TRANSLATION PROCESS OF EGIDIO DA VITERBO'S QUR'ĀN
}

\author{
Katarzyna K. Starczewska \\ Consejo Superior de Investigaciones Cientificas \\ katarzyna.starczewska@cchs.csic.es
}

\begin{abstract}
Together with manuscript MS D Ioo inf. from the Biblioteca Ambrosiana in Milan, which preserves the Latin translation of the Qur'àn (produced for the first time in ${ }^{5} \mathrm{I} 8$ and then corrected until the year I62I), there are ca. 20 folios of a smaller dimension filled with notes discussing the tradition of the presented interpretation. The annotations, based on the Muslim authorities, constitute a first-hand testimony of how the Qur'ān was understood and studied in the seventeenth-century Europe. The aim of this paper is to discuss some of these notes.
\end{abstract}

During the elaboration of my PhD dissertation on the I5I8/I62I translation of the Qur'ān ${ }^{\mathrm{I}}$, in one of the manuscripts I have encountered numerous folios which do not pertain to the actual translation but instead are explanations of the qur'anic context, usually based on Arabic authorities, occasionally quoting them by name, occasionally alluding to them in general. These notes have gained scholarly interest (Burman 2005, 2007) but have never been edited or studied in their entirety. Although the use of qur'anic commentaries whilst translating the Muslim Holy Book into Latin has already been demonstrated in the previous translations (Burman, 1998), what makes the I518/162I translation special is the stern division between the text and the gloss (Burman, 2007, p. 157-177).

Broadly speaking, the notes in question refer to some elements which were relevant to European Christians working with the Muslim sacred text. One of the subjects that concerned them in particular is the discrepancies and similarities between the biblical and qur'anic narrations, for example, about the Forbidden Tree (mentioned in the gloss to the verse 2:35), the expulsion from Paradise (2:38) or Moses and the Golden Calf $(2: 55)^{2}$. Other glosses focus on the specific terms,

I Latin Translation of the Qur'ān (ISI8/I62I) commissioned by Egidio da Viterbo. Critical Edition and Introductory Study, supervised by Dr Óscar de la Cruz Palma (20I2).

2 Milan, Biblioteca Ambrosiana, MS D roo Inf $(M)$, f. 5. 
struggling to explain their meaning within the specific context of the qur'anic verse, for instance of the word "Qur'ān" (Alforcan as opposed to Alcoran, 2:53) or Rahine (2:104) ${ }^{3}$. The third category would include elements regarded as surprising or exotic, such as providing details on God turning Jews into monkeys $(2: 65)^{4}$ or on the abrogation of the verses on stoning (2:106)s.

According to the copyist's testimony ${ }^{6}$, in the original version commissioned by Egidio da Viterbo in 1518 the notes were to be consulted side by side with the Latin text of the Qurān, together with the Arabic original and its phonetic transliteration, providing in such a way a useful philological tool to study both the religious tradition and the Arabic language. It is said that in the original text, now lost, there were four columns. The columns included (I) the Arabic text, still present in the manuscripts ${ }^{7}$, (2) the transliteration into Latin alphabet, now lost, (3) the original translation together with some corrections and (4) the notes which were copied by the copyist into one of the manuscripts. The reconstruction of the original layout in four columns would look as in Table I (infra).

We can see that verses 2:121 ${ }^{8}, \mathrm{I} 25^{9}, \mathrm{I} 26^{\mathrm{IO}}, \mathrm{I} 27-\mathrm{I} 28^{11}$ and $129^{\mathrm{I2}}$ are accompanied by explanations, which read as in Table 2 (infra).

$3 M$, f. $4 \mathrm{I}-4 \mathrm{O}$ (in this order).

4 , f. 4 I.

$5 M$, f. 40 .

6 A three-folio prologue written by a Scottish Orientalist, David Colville (Starczewska, 20I2 ${ }^{1}$, pp. XXI-XXIII, XXVI).

7 The translation in question is preserved in two manuscritpts: Cambridge University Library, MS Mm. v. $26(C)$ and Milan, Biblioteca Ambrosiana, MS D Ioo Inf $(M)$. However, the Cambridge manuscript is incomplete and the Arabic text has been only partially copied there (Starczewska, $2012^{1}$, pp. XL-XLV).

8 "Those to whom We have sent the Book study it as it should be studied: They are the ones that believe therein: Those who reject faith therein,- the loss is their own”. All the Qur'anic quotes in English according to Yusuf Ali, 1934, The Qur'an. Text, Translation and Commentary.

9 "Remember We made the House a place of assembly for men and a place of safety; and take ye the station of Abraham as a place of prayer; and We covenanted with Abraham and Isma'il, that they should sanctify My House for those who compass it round, or use it as a retreat, or bow, or prostrate themselves (therein in prayer)".

Io "And remember Abraham said: 'My Lord, make this a City of Peace, and feed its people with fruits, — such of them as believe in Allah and the Last Day'. He said: '(Yea), and such as reject Faith,-for a while will I grant them their pleasure, but will soon drive them to the torment of Fire, —an evil destination (indeed)!”.

II "And remember Abraham and Isma'il raised the foundations of the House (With this prayer): 'Our Lord! Accept (this service) from us: For Thou art the All-Hearing, the All-knowing. / Our Lord! make of us Muslims, bowing to Thy (Will), and of our progeny a people Muslim, bowing to Thy (will); and show us our place for the celebration of (due) rites; and turn unto us (in Mercy); for Thou art the Oft-Returning, Most Merciful”.

I2 "Our Lord! send amongst them a Messenger of their own, who shall rehearse Thy Signs to 
As Thomas Burman has stated (Burman, 2007, p. I6I), the commenters quoted are al-Zamakhsharī, Ibn 'Ațìyah and al-Bukharī, although often Islamic authorities are simply called interpretes, as in the note which accompanies verse 2:55-56 ${ }^{13}$. Beside the qur'anic text which reads: "Et quando dixistis: 'O Moyses, non credemus tibi donec uideamus Deum clare'. Vbi percussit uos fulmen uobis uidentibus. / Et postea resciuscitauimus uos a mortuis, ut essetis grati", there is the following explanation: "Dicunt interpretes quod erant septuaginta barones (ut loquitur glossa ex qua ista descripsi) qui non credebant Moysi si non uiderant Deum clare, quos fulmen descendens e caelo interemit; sed postea Moyses precibus suis eos a mortuis resuscitauit et de hac resuscitatione hic loquitur cuius meminit praeterea lib. I2, cap. I, uers. I52". Such an interpretation of these verses is found in "for example, al-Ṭabarī on 2:55-56, I.33I" (Burman, 2007, p. I6I, n. 38 , p. 274).

Other than the glossae which provide further information about the qur'anic context, there are also more informal annotations of the copyist which may reflect for example his emotional attitude towards philological difficulties of the text; as, for instance, a gloss which makes a reference to the verse I3:I5" "Et Deo humiliat qui est in caelis et in terra, obedientes aut coacti, et umbrae eorum in mane et in sero", it comments on the phrase "in mane et in sero". Together with an explanation ("arabice inquit: 'Intelligunt per mane "prandium» et per serum «applicationem»") $)^{\text {I5 }}$ in the note one can find a declaration by a surprised copyist: "Sic erat scriptum, nec potui aliter legere".

As per negative comments on the qur'anic content, so often found in the Robert of Ketton's translation (II42-43), they are scarce in this text ${ }^{16}$. The general tone of these remarks, when they appear, can be considered sarcastic rather than hostile. For example, next to the header of chapter eighteen, Caput de Antro, there is the following note: "de antro isto loquuntur uersu 7 et sequentes, et omnia sunt inaudita nobis, de Alexandro Magno quam ridicula dicit!". A similar, brief comment appears next to the heading of chapter twenty-seven, Caput de Formicis:

them and instruct them in scripture and wisdom, and sanctify them: For Thou art the Exalted in Might, the Wise"'.

I3 "And remember ye said: 'O Moses! We shall never believe in thee until we see God manifestly', but ye were dazed with thunder and lightning even as ye looked on. / Then We raised you up after your death: Ye had the chance to be grateful".

I4 "Whatever beings there are in the heavens and the earth do prostrate themselves to God (acknowledging subjection), —with good-will or in spite of themselves: So do their shadows in the mornings and evenings".

I5 I thank Prof. Víctor Pallejà de Bustinza for his insight on this fragment.

I6 Although there are notes which make clear reference to Robert of Ketton's translation, consulted most probably in Bibliander's edition. See $M$, f. 599 . 
"De formicis istis uide uersum I8 et abstine risu". The subjects which had fueled Latin literature of religious controversy for so long, such as the trinity or the unity of God or the figure of Jesus, are not excessively exploited. There are a couple of very short notes, for instance the one to the verse II2:3 "non fuit generatus neque generabit", which states: "non desiuit negare filium Dei"; the explanatory and philological notes, however, populate far more entries.

One might wonder why the glosses favoured philology over polemics and sarcasm over hostility. If I were to venture an opinion on the reasons, I would mention two factors; firstly, the preferences of the copyist, David Colville, who would frequently dialogue with the gloss, placing his personal statement, however unfavourable it may be, together with the information he copies (Starczewska $\left.2012^{2}, 2013\right)$. Since the copyist portrays himself as a learned scholar, he sees it necessary to mark the distance between his own beliefs or notions and the information he reads and repeats. The reason behind the limited polemical content could be linked with the fact that the source is a manuscript, not a printed edition, as was the one of Bibliander's ( 1543 , I550, 1556) or the translation of Marracci's (I698). The printed editions state clearly that the lecture of the Qur'an should be performed for disputatious purposes; not only do they highlight the controversial content but also they often remind the reader how it differs from the Christian teachings, and therefore should be regarded as erroneous (Burman 2007). The case of Egidio da Viterbo's translation is different: as far as we know, it was never designed to be edited, and since its first version (I5I8) it had contained elements which would facilitate a philological study, thus the notes in question should most probably be regarded as one of the philological tools (which can also be used for polemical purposes, if one wishes).

Identifying, as precisely as possible, the Muslim sources behind these notes is by all means one of the priorities in my path as a researcher. There is, however, another important aspect which has to be taken into consideration, namely the relation of the Latin qur'anic annotations with the ones written in vernacular. Presenting the text of the Qur'ān, also in transliteration, together with its interpretation was a common practice in the sixteenth-century literature of conversion written by such authors as Juan Andrés, Martín García or Bernardo Pérez de Chinchón. The qur'anic notes constitute, on the one hand, a complementary material of the translation; on the other hand, however, they may form a part of a larger current in which the medieval Muslim authorities were often quoted. 


\section{BIBLIOGRAPHY}

Yusuf Ali, A., 1934: The Qur'an. Text, Translation and Commentary, New York (reed. 200I).

Burman, T., 1998: "Tafsìr and Translation: Traditional Arabic Qur'ān Exegesis and the Latin Qur'āns of Robert of Ketton and Mark of Toledo", Speculum, $73,703-32$.

—_, 1998-1999: "Exclusion or Concealment: Approaches to Traditional Arabic Exegesis in Medieval-Latin Translations of the Qur'ān”, Scripta Mediterranea, XIX-XX, I8I-97.

— 2002: "Cambridge University Library MS Mm. V. 26 and the History of the Study of the Qur'ān in Medieval and Early Modern Europe", in Religion, Text, and Society in Medieval Spain and Northern Europe. Essays in honor of J. N. Hillgarth, in Th. E. Burman, M. D. Meyerson, and L. Shopkow (eds.), Toronto, 335-63.

— 2005: "The Latin-Arabic Qur'ān Edition of Egidio da Viterbo and the Latin Qur'āns of Robert of Ketton and Mark of Toledo”, in Barceló and Martínez Gázquez (2005), I03-II7.

—, 2007: Reading the Qur'ann in Latin Christendom, II40-1560, Philadelphia, Pennsylvania.

Starczewska, K. (ed.), 20I2': Latin Translation of the Qur'an (ISI8/I62I) commissioned by Egidio da Viterbo. Critical Edition and Introductory Study, PhD diss., Universitat Autònoma de Barcelona, Barcelona.

— 2012: "Critical edition of Egidio da Viterbo's Latin Translation of the Qur'ān (I5I8): some methodological problems", in Estudiar el pasado: aspectos metodológicos de la investigación en Ciencias de la Antigüedad y de la Edad Media. Proceedings of the First Postgraduate Conference on Studies of Antiquity and Middle Ages, Universitat Autònoma de Barcelona, 26-28th October 20I0, A. Castro Correa, et al. (eds.), Oxford, 353-359.

_ - 2013: "Los primeros orientalistas frente al islam: la traducción latina del Corán del círculo del cardenal Egidio de Viterbo (I5I8)", in Religio in labyrintho. Encuentros y desencuentros de religiones en sociedades complejas, J. J. Caerols (ed.), Madrid, I45-I55. 


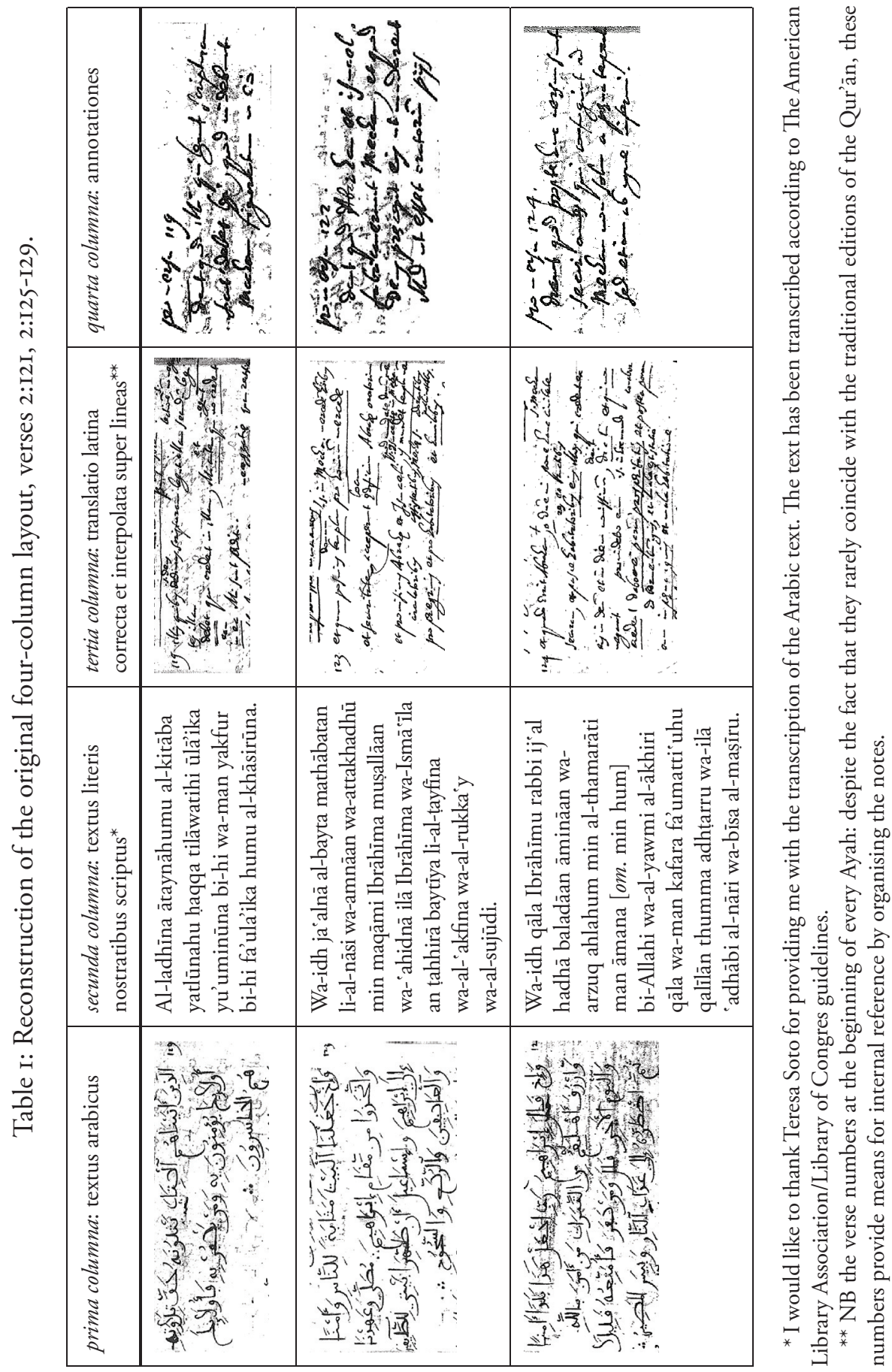




\begin{tabular}{|c|c|c|}
\hline 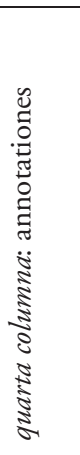 & 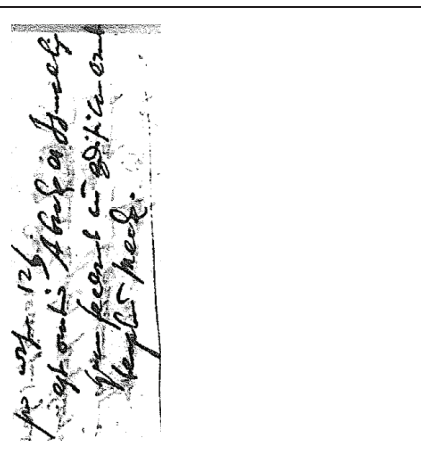 & 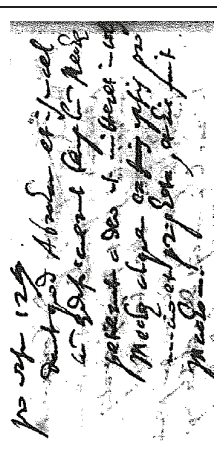 \\
\hline 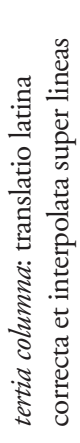 & 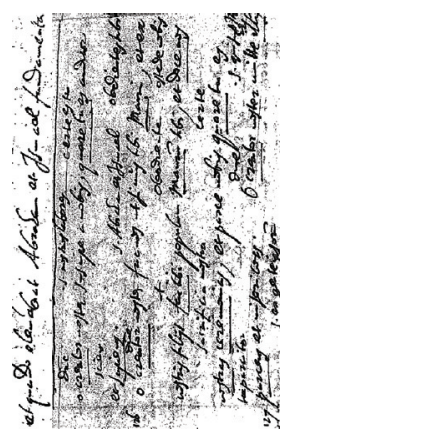 & 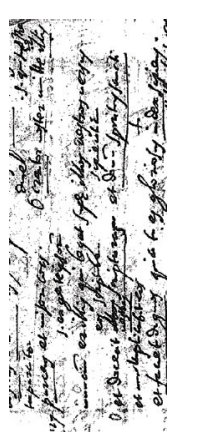 \\
\hline 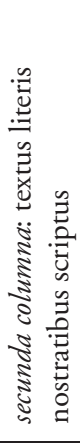 & 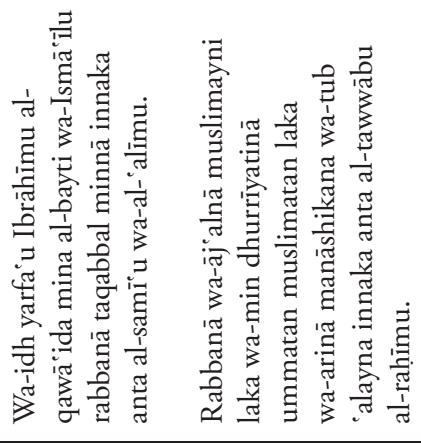 & 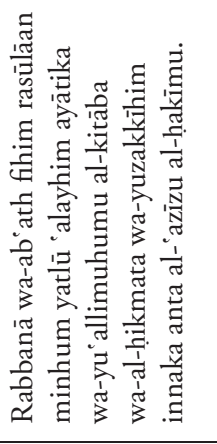 \\
\hline 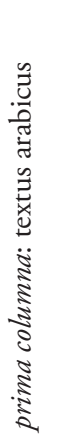 & 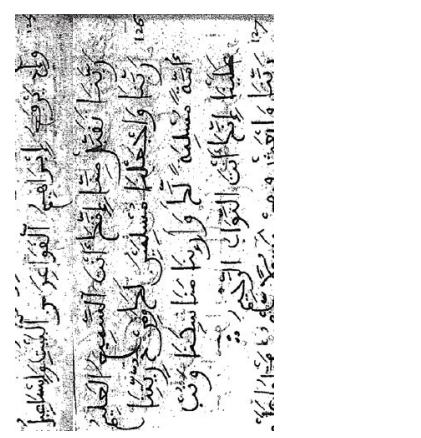 & 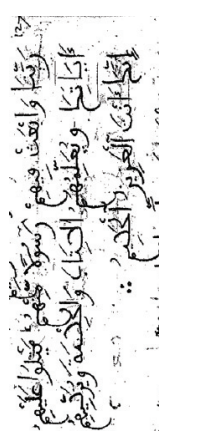 \\
\hline
\end{tabular}


Table 2: Verses 2:I2I, 2:I25-I29: the Qur'anic text and the gloss

\begin{tabular}{|c|c|c|}
\hline Verse & Translation* & Annotation $^{* *}$ \\
\hline $2: 121$ & $\begin{array}{l}\text { Illis quibus dedimus scripturam, } \\
\text { legent illam quemadmodum debet } \\
\text { legi, qui credent ei; illi autem, qui } \\
\text { non credent, erunt perditi. }\end{array}$ & $\begin{array}{l}\text { Pro uersu 119: Dicunt quod illi qui } \\
\text { legunt scripturam sicut debet legi, } \\
\text { quod uidebunt Machom figuratum } \\
\text { in eo. }\end{array}$ \\
\hline $2: 125$ & $\begin{array}{l}\text { Et quando posuimus templum pro } \\
\text { hominibus, quod est premium et } \\
\text { securitas, acceperunt ex aedificio } \\
\text { Abraham oratorium, et iam promisi- } \\
\text { mus Abraham et Ismaeli quod mun- } \\
\text { dassetis templum meum peregrinis } \\
\text { et habitatoribus et humilibus et pros- } \\
\text { tratis se. }\end{array}$ & $\begin{array}{l}\text { Pro uersu 122: Dicunt quod Abraham } \\
\text { et Ismael fabricauerunt Mecham et } \\
\text { quod Deus praecepit eis ut mundar- } \\
\text { ent illud ut esset oratorium piis. }\end{array}$ \\
\hline $2: 126$ & $\begin{array}{l}\text { Et quando dixit Abraham: "O creator } \\
\text { meus, pone istam ciuitatem securam } \\
\text { et pasce habitatores eius fructibus } \\
\text { eius et illos qui crediderunt ex ipsis } \\
\text { in Deum et in diem nouissimum". } \\
\text { Dixit: "Et qui non credidit, ego dabo } \\
\text { ei minimam prosperitatem, et postea } \\
\text { ego praeparabo ei poenam ignis et } \\
\text { malam habitationem". }\end{array}$ & $\begin{array}{l}\text { Pro uersu 124: Dicunt quod propter } \\
\text { hunc uersum sunt securi omnes qui } \\
\text { confugiunt ad Mecham, non solum } \\
\text { a poena temporali sed etiam ab igne } \\
\text { inferni. }\end{array}$ \\
\hline $2: 127-128$ & $\begin{array}{l}\text { Et quando eleuabant Abraham et } \\
\text { Ismael edificia templi, dicebant: "OO } \\
\text { creator noster! Suscipe a nobis, quia } \\
\text { tu es auditor et sapiens. / O Creator } \\
\text { noster! Fac ut nos simus tibi mauri, } \\
\text { et de filiis nostris fac tibi populum } \\
\text { maurum, et doce nos cerimonias nos- } \\
\text { tras, et parce nobis; quoniam tu es par- } \\
\text { cens, et misericors, et creator noster. }\end{array}$ & $\begin{array}{l}\text { Pro uersu 125: Est oratio Abrahae et } \\
\text { Ismaelis quam fecerunt cum aedifi- } \\
\text { cauerunt templum Mechae. }\end{array}$ \\
\hline $2: 129$ & $\begin{array}{l}\text { Mitte illis unum nuncium ex illis qui } \\
\text { legat super illos uestros uersus et } \\
\text { doceat uestras scripturas et donum } \\
\text { spiritus sancti et faciet dignos, quia } \\
\text { tu es gloriosus iudex sapiens". }\end{array}$ & $\begin{array}{l}\text { Pro uersu 125: Dicunt quod Abra- } \\
\text { ham et Ismael, cum aedificauerunt } \\
\text { templum Mechae, petierunt a Deo ut } \\
\text { mitteret incolis Mechae aliquem ex } \\
\text { ipsis pro nuncio et propheta; et hic } \\
\text { fuit Machom. }\end{array}$ \\
\hline
\end{tabular}

* Given the discrepancies between and within the manuscripts (Starczewska, 20I2², p. XLVI-L) it should be stated that the translation quoted here is based on the Cambridge ms, although the notes are extracted from the Milan ms. See table I for comparison between the Cambridge and Milan translations.

${ }^{* *} M$, f. 2 . 